\title{
UNIFIED THEORY OF ACCEPTANCE USE OF TECHNOLOGY (UTAUT) AND ITS APPLICABILITY TO MORTGAGE BANKING DIGITIZATION: THE CASE OF THE PHILIPPINES
}

\author{
Dave T. Morales ${ }^{1}$ \\ Ph.D. student, Commerce, The Graduate School, University of Santo Tomas, Manila, Philippines. \\ (Email: dave_t_morales@yahoo.com) \\ Fernando L. Trinidad, Ph.D. ${ }^{2}$ \\ Professorial Lecturer, The Graduate School, University of Santo Tomas, Manila, Philippines
}

Received date: 11-07-2019

Revised date: 29-07-2019

Accepted date: 09-08-2019

Published date: 12-09-2019

To cite this document: Morales, D. T., \& Trinidad, F. L. (2019). Unified Theory of Acceptance Use of Technology (UTAUT) and Its Applicability to Mortgage Banking Digitization: The Case of the Philippines. Journal of Information System and Technology Management, 4(14), 47-60.

DOI: $10.35631 /$ jistm. 414005

\begin{abstract}
The advent of technology has influenced the way banks should conduct its business. People are becoming more conscious, more discerning and more critical with the way how businesses should provide efficient, fast, and convenient access to their products and services. And banks are not exempted from these expectations. There has been a steady surge of innovative technology that will help banks deliver more efficient services through digitization. This study was conducted to investigate the determinants of the behavioral intentions on the acceptability of the bank's digital mortgage service from the perspective of 250 mortgage clients who are current or prospective users of digital mortgage service. The study was anchored from the Unified Theory of Acceptance Use of Technology (UTAUT). The research has found that the determinants of behavioral intention to accept digital mortgage device among mortgage clients were facilitating conditions, performance expectancy and effort expectancy. It was also revealed that based on the standardized beta coefficients, facilitating conditions (0.405), performance expectancy (0.383) and effort expectancy (0.134) had a significant influence on bank mortgage clients' behavioral intentions to accept digital mortgage service. Additionally, it was also proven that the age, education, computer knowledge and internet knowledge of the mortgage clients moderate the impact of the three determinants: performance expectancy, effort expectancy and social influence on clients' digital mortgage service acceptance. Lastly, it can be concluded that performance expectancy is directly related to internet time, frequency of product purchase using a mobile device and use of mobile banking.
\end{abstract}




\section{Introduction}

The world today takes cognizance on the importance of technology as an important factor for operational efficiency in response to the increasing clamour of people looking for convenience. Everything seems to be becoming digital. Digital in operational sense means fast, efficient, convenient, and accurate.

The financial sector more particularly the banking industry is not excused to the idea of becoming digital. The IT industry has sensed the need for the finance sector to transform digitally as it promises to make banking services more convenient and efficient. These evolution in fintech products, are making a new wave in the finance sector which is now becoming a revolution in the industry where bank customers' access to financial products is just at the tip of their fingers.

Chen and colleagues (2014) envisaged that banks can generate significant value in digital banking using a range of tactics and methods, from digitally enabling their current model that would allow higher sales force productivity and embracing disruptive new propositions, such as new consumer concepts for targeted segments.

Amid the following decades, banking and financial sectors are growing quicker than an an other time and in this manner, digitization is a key competitive advantage between competing banks. With the new period of digitization in the banking sector, the day-by-day tasks are resulting in less expensive and simpler products and services for clients to utilize. Along these lines, each bank is learning a handle on to alter their own tasks to fit the necessities of a demanding client.

Although each Asian country may be at different phases of evolution toward complete digitalbanking readiness, Asian market consumers are already using or interested in using alternative channels to interact with banks. And this development is also observed in mortgage banking. The Business World (2018 June 26) further stated that four in ten Filipinos in the workforce are digitally savvy. Technology, therefore can change the way banks do business with the convergence of internet, wireless technologies and mobile advancement.

Eventually, the improvements that can be realized through digitization and the benefits to compliance, customer experience, asset quality, and efficiencies lead to a more streamlined, faster, and less expensive mortgage process.

Despite witnessing the multiple digitization activities in many Asian countries, the Philippine mortgage industry still seems to be in the wait-and-see mode. The borrower engagement approach of today's leading bank lenders is incongruent and not truly "digital." Most bank mortgage system in the Philippines continues to provide fragmented collaboration solutions that are heavily call-center-based. Customers are able to initiate the loan application process using the bank's online PoS platform or interface, but in most cases, the document collection and additional borrower information are obtained through other channels such as call contact, e-mail, and portal connections, among others. 
Given that the UTAUT model by Venkatesh et al. (2003) has accounted for up to $70 \%$ accuracy in predicting user acceptance of information technology innovations (Amofa, 2014), this theory will be used in this study to investigate the important drivers of bank executives' and mortgage clients' acceptance of mortgage digitization. This shall employ quantitative and qualitative research methodologies that will utilize bank executives and mortgage clients' perceptions and acceptance of bank mortgage digitization.

\section{Research Questions}

This study specifically addressed the following research questions:

1. What are the determinants of bank mortgage clients' behavioral intention to accept digital mortgage service?

2. To what extent are the four constructs of UTAUT model such as: performance expectancy, effort expectancy, social influence, and facilitating conditions influence bank mortgage clients' behavioral intentions to accept digital mortgage service?

3. To what extent do the moderating variables (gender, age, and, technology experience) impact the three determinants (performance expectancy, effort expectancy, and social influence) of the bank's digital mortgage service acceptance?

\section{Literature Review}

\section{Digitalization}

Digitalization is an opportunity for companies and organizations to improve their business activities. Due to the technological advances and digitalization, the interaction between companies and official authorities to consumers and citizens has also been improved and created new ways of reaching one another. This can easily be seen in the commercial banking sector, where digitalization has given the banks more ways of reaching potential customers and at the same time, helped them to improve their services.

A home loan bank must have thoroughly considered design innovation. It ought to be custom fitted to the bank's particular plan of action, in light of the fact that there is no innovation arrangement that is a general fit for all organizations. Speculators that are thinking about cooperation in the home loan managing an account industry will discover two boundlessly extraordinary states of mind toward innovation.

\section{Mortgage Loan}

The mortgaged property may be owned by the mortgage loan (ML) applicant or another person, e.g. a family member. In the past century mortgage loans concerned primarily capital project financing. Such investments related to business activities and catering for housing needs. Over the course of history, several different methods of mortgage financing have evolved in developed economies (Múčková \& Hrnčiarová, 2010).

The processes of liberalization, financial markets deregulation, globalization and technological progress have significantly changed the bank operating environment - enhanced market competition and created the necessary prerequisites for performance evaluation and management on the market (Buriak, 2014). 
Loan approval organizations depend on their clients and therefore should understand their current and future needs, they should meet their requirements and should be concerned with exceeding their expectations. This means understanding the fact that profitability or avoiding losses comes from customer satisfaction, which implies organizing all the processes and directing the entire staff towards the client (Dragolea, Achim, \& Fleser, 2011).

A fundamental question about mortgage markets - and markets in general - is whether the classic economic assumptions of rationality hold. If consumers are capable of making rational assessments of financial risk, then providing them with more information about the terms of their mortgage contract and what might happen under various scenarios will lead them to make to better decisions (Scanlon, Lunde, \& Whitehead, 2011).

A proficient housing framework has critical significance both in meeting the lodging needs of people and in fortifying the advancement of the development, back and other related parts of an economy. Worldwide experience proposes that, the broad accessibility of private home loans has positive effect on neediness mitigation, nature of lodging, foundation, and urbanization. Money related and other conduct experts routinely figure corporate profit, money streams, loan costs, expansion rates, trade rates, stock costs, product costs, GDPs, and numerous other monetary and budgetary factors. In making such expectations, inside and master data with respect to the factors being considered would be very important (Ray, 2006).

\section{Unified Theory of Acceptance and Use of Technology (UTAUT)}

The acceptance of digitization in mortgage banking is an important factor in determining the success of this technology. This study uses the Unified Theory of Acceptance and Use of Technology (UTAUT), a prominent technology acceptance and use model, as a theoretical basis to conduct empirical research testing the factors that influence mortgage clients' acceptance of digital mortgage banking. The primary goal of this research study is to test UTAUT in the framework of the mortgage industry focusing on digital mortgage banking.

Venkatesh, Morris, Davis, and Davis (2003) have synthesized eight user acceptance and motivation models to come up with the Unified Theory of Acceptance and Use of Technology which serves as the theoretical foundation of this study. The eight theories combined by Venkatesh et al. (2003) to form the UTAUT model are the Theory of Reasoned Action (TRA), the Technology Acceptance Model (TAM), the Motivational Model (MM), the Theory of Planned Behavior (TPB), a combined theory of Planned Behavior/Technology Acceptance Model (C-TPB-TAM), the Model of PC Utilization (MPCU), Innovation Diffusion Theory (IDT), and Social Cognitive Theory (SCT).

The UTAUT suggests that four core constructs are direct determinants of technology acceptance (behavioral intention) and use (behavior): Performance Expectancy, Effort Expectancy, Social Influence, and Facilitating Conditions. The theory also suggests that the effect of these four constructs is moderated by four other variables: age, gender, experience and voluntariness of use.

Venkatesh et al. (2003) created UTAUT based on their identification of certain factors they considered to be significant in effecting a person's decision on whether or not to adopt a particular new technology. In the development of the UTAUT model, the predictors of intention of use and acceptance are collapsed into four final constructs: performance expectancy, effort expectancy, social influence, and facilitating conditions. Performance 
expectancy, effort expectancy, and social influence are direct determinants of behavioral intention, while facilitating conditions is a direct determinant of user behavior.

Performance expectancy is the degree to which an individual believes that using a particular system would improve his or her job performance. It refers to the adopter's estimate for the potential benefit that the use of technology may bring. Effort expectancy is the degree of simplicity associated with the use of a particular system. Social influence is the degree to which an individual perceives that others believe he or she should use a particular system. Facilitating conditions refers to the degree to which an individual believes that an organizational and technical infrastructure exists to support the use of a particular system.

In addition to the four constructs, Venkatesh et al. (2003) have identified four key moderators that have an influence on the four constructs. Moderators are characteristics of the participant, such as gender, that have an influence on the relationship between constructs and the dependent variable. The moderators are gender, age, voluntariness and experience. The UTAUT instrument will have different results depending on gender, age, experience of the user, and whether the technology use is mandatory or not.

\section{Process Flow of Mortgage Loan Approval}

A major task for a bank is to offer loan facilities to firms and individuals and this require short and long-term capital, thus deposits are transformed to loans. The products offered by the banks such as deposits and loans require decisions on several variables such as the term period of the loan. Part of loan operations is for the bank to assume risks such as liquidity risk, interest rate risk, currency risk and credit risk.

One article by Samonte (2015) of Hoppler.com compared the housing loan approval and processing time comparison in various banks in the Philippines. This depicted the length of time it takes before an application gets approved.

Samonte (2015) explained that applying for a home loan in the Philippines cannot be rushed as it goes through a detailed review process. Basically, after pre-approval, a home loan specialist will advise the borrower to provide supporting documents which will be submitted to the underwriter. It is then the underwriter's responsibility to review the borrower's loan scenario and the supporting documentation to ensure that it meets the loan program guidelines and to determine whether the borrower is qualified for the loan. Afterwards, a decision will be tendered by the underwriter, typically through a letter or a call, with one of the four possibilities about the application: approved, approved with conditions, suspended (more documentation required) or denied. The bank will check the borrower's current standing from all the documents he submitted.

Figure 1 shows the housing loan approval and processing time comparison guide in various banks and lending institutions in the Philippines. 


\begin{tabular}{|c|c|c|}
\hline \multirow{2}{*}{\multicolumn{2}{|c|}{ Bank }} & \multirow{2}{*}{$\begin{array}{l}\text { Number of Working Days } \\
12 \\
134\end{array}$} \\
\hline & & \\
\hline 1 & S SECURITY BANK & \\
\hline 2 & $\Leftrightarrow$ easturest & \\
\hline 3 & $\mathbf{\gamma}$ & \\
\hline 4 & UNIONBANIK & \\
\hline 5 & BPI & \\
\hline 6 & 26. CTEC BANK & \\
\hline 7 & (69) Maybank & \\
\hline 8 & PSBank & \\
\hline 9 & 용 Metrobank & \\
\hline 10 & AIIILED BANK & \\
\hline 11 & EGMINABANK & \\
\hline 12 & & \\
\hline 13 & & \\
\hline \multirow{2}{*}{\multicolumn{2}{|c|}{ Lending Institution }} & Number of Working Days \\
\hline & & $\begin{array}{llllllllllllllll}1 & 2 & 3 & 4 & 5 & 6 & 7 & 8 & 9 & 10 & 11 & 12 & 13 & 14 & 15\end{array}$ \\
\hline 14 & (2) Pag-1BiG & - \\
\hline 15 & Wh sacun, SEcurem & \\
\hline
\end{tabular}

\section{Figure 1: Housing Loan Approval and Processing Time Comparison Guide in Various Banks and Lending Institutions in The Philippines (Samonte, 2015)}

\section{Research Methodology}

This study used the UTAUT model as the conceptual basis which was evaluated using a sequence of quantitative data and analysis in order to produce a final model that best explains the predominant phenomena of the data that were collected. This also tested a set of hypotheses to understand and study the effect between the UTAUT model's main constructs. Thus, the quantitative approach was chosen to be the primary approach for this study to examine and study the proposed research model.

A self-made questionnaire was used as the primary survey instrument. To ascertain the validity and reliability of the survey questionnaire, a pre-test was done among ten mortgage clients and five mortgage bank employees in a universal bank not included in the study. Thereafter, the pre-test Likert questionnaire was tested using Cronbach alpha $(\alpha)$. All Cronbach $\alpha$ coefficients for all scales that were used in the questionnaire were computed by the statistician and all values greater than 0.7 were considered acceptable for conducting research.

There were two hundred fifty (250) respondents who are both existing and prospective mortgage clients who answered the survey questionnaires.

To test the first four hypotheses, a correlation analysis was conducted with the five variables, behavioral intention score (BI) as the dependent variable and the four independent variables as performance expectancy score (PE), effort expectancy score (EE), social influence score 
(SI), and facilitating conditions score (FI). To determine if there is any correlation between the five variables, a correlation analysis was performed using Pearson $r$ correlation.

The multiple regression analysis was used to predict the importance of the independent variables. To find out how the moderating factors of age, gender, and technology experience predict behavioral intention to accept digital mortgage banking, a multiple regression analysis was used.

\section{Research Ethics}

The research study conformed to all the ethical considerations as required by the UST Ethics Review Committee. As indicated by the UST Ethics Review Committee, this research study must contain the following: Background of the Study; Significance of the Study; Rationale of Study; Objectives of Study; Statement of benefits of the project; Recruitment of participants; Methods; and Informed consent. All of these items were incorporated in this research work.

\section{Theoretical Framework}

Figure 2 displays the relationships between constructs and behavior intention and use behavior.

The UTAUT model theorizes that four variables (performance expectancy, effort expectancy, social influence, and facilitating conditions) are direct determinants of the behavioral intention of technology use. Behavioral intention and facilitating conditions are direct determinants of use behavior. The model also incorporates four moderating factors (gender, age, experience, and voluntariness of use), each of which may have influence on the four primary constructs.

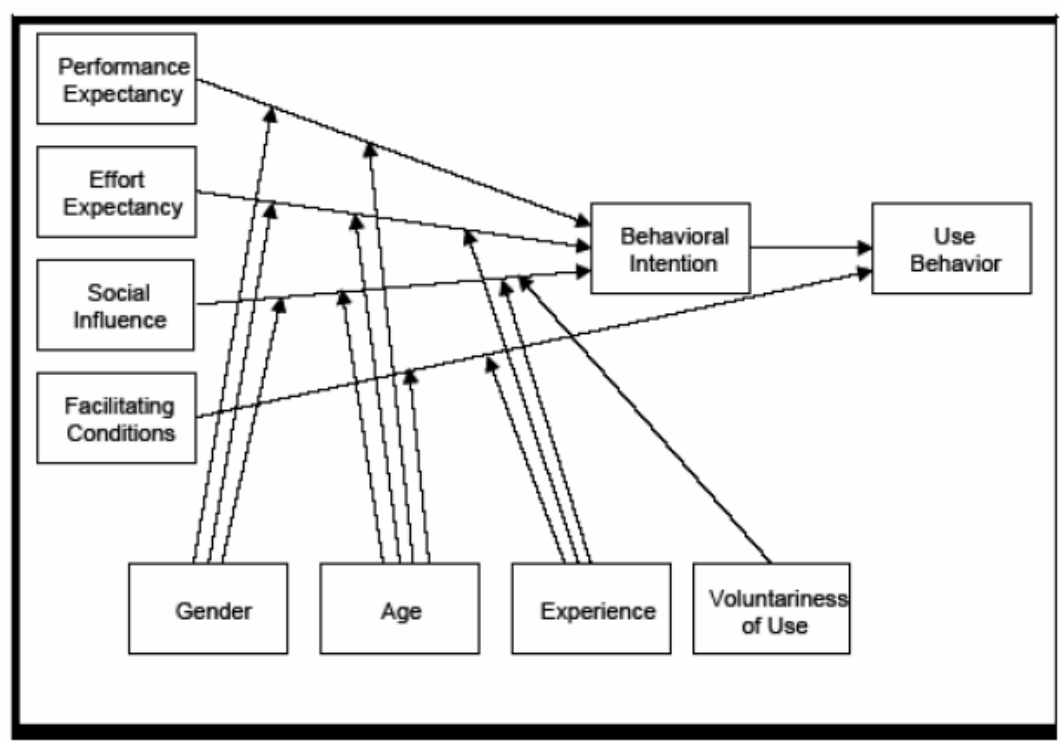

Figure 2: Unified Theory of Acceptance and Use of Technology (UTAUT Model) by Venkatesh, V., Morris, M., Davis, G., \& Davis, F. (2003). 


\section{Research Framework}

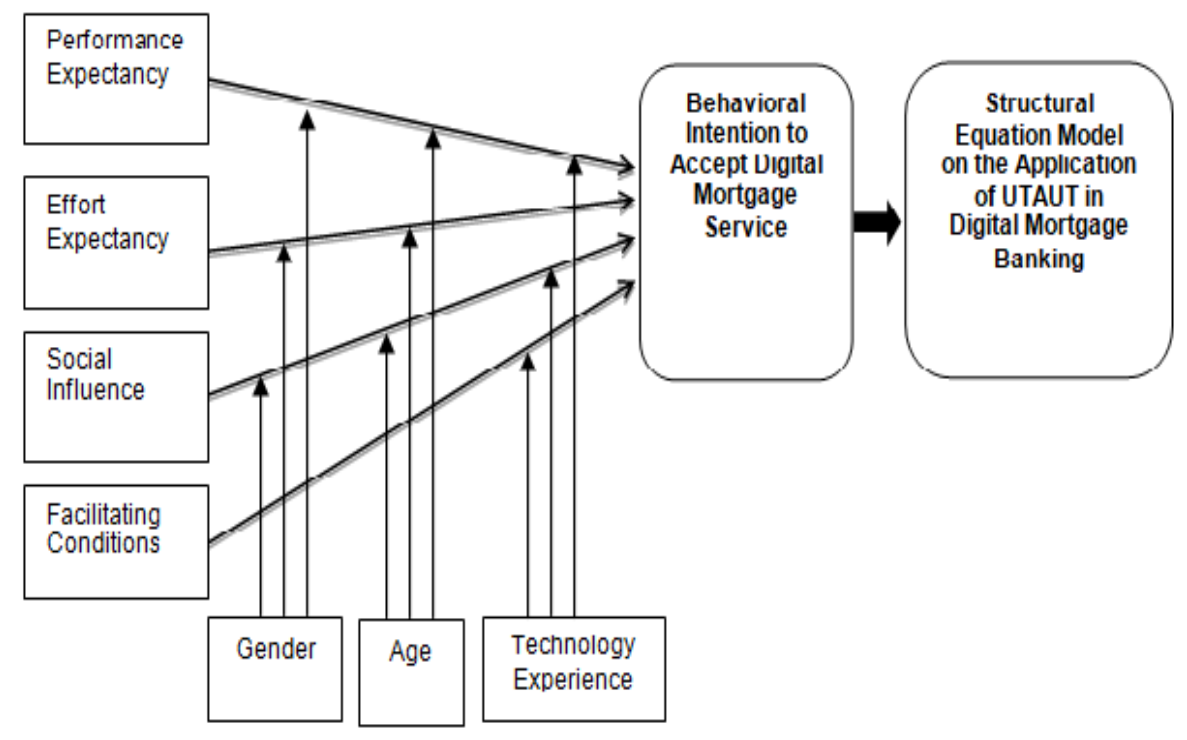

Figure 3: The Conceptual Framework

The research framework illustrates the hypothesized relationships between the independent and dependent variables. The independent variables were adopted from the four main constructs of UTAUT model such as: performance expectancy (PE), effort expectancy (EE), social influence (SI), and facilitating conditions (FC), while the dependent variable is the behavioral intention (BI) to accept the bank's digital mortgage service.

The first independent variable in the proposed research model is performance expectancy described as the degree to which individuals believe that using a system will help them improve their job performance (Venkatesh et al., 2003). For this study, PE will be measured based on the perceptions of mortgage clients in using the banks digital mortgage service in terms of benefits (saving time, money and effort, facilitating communication with the bank, improving the quality of mortgage service, and by providing clients with an equal opportunity to carry out their mortgage application with the bank).

Effort expectancy refers to the degree of ease associated with the use of the system (Venkatesh et al., 2003). EE will be measured by the mortgage clients' perceptions on the ease of use of the bank's digital mortgage service, as well as the ease of learning how to use the service.

Social influence refers to the degree to which significant others influence the use of the system (Venkatesh et al., 2003). This variable will be measured by the perception of how significant others influence mortgage clients' use of the bank's digital mortgage service.

Facilitating conditions refers to the degree to which an individual believes that an organizational and technical infrastructure exists to support the use of a particular system (Venkatesh et al., 2003). This variable will be measured by the perception of mortgage clients 
being able to access required resources, as well as to obtain knowledge and the necessary support to use the bank's digital mortgage service.

The dependent variable behavioral intention (BI) is defined as the person's subjective possibility that he or she will perform the behavior in question (Venkatesh et al., 2003). In this study, behavioral intention will be measured by the intention, prediction, and planned use of the bank's digital mortgage service.

Moreover, the proposed research model also indicates that the relationships between the independent and dependent variables may be moderated by three variables. In the original model of Venkatesh et al. (2003), the four independent constructs may be affected by four moderating variables. However, for this study the model will only determine the effect of three moderating factors (gender, age, and, technology experience) on the three UTAUT determinants (performance expectancy, effort expectancy, and social influence). The moderating factor of voluntariness of use will not be covered since the acceptance of digital mortgage service operates on a voluntary situation and not in a mandated context.

The ultimate goal of this research is to develop a structural equation model based on the hypothesized relationships with the application of UTAUT model in digital mortgage banking in the Philippines.

\section{Hypotheses}

Using the research framework as reference, the following hypotheses were drawn and tested:

Hal: Performance expectancy has a positive effect on behavioral intention of the respondents to accept digital mortgage service.

$\mathrm{Ha2}$ : Effort expectancy has a positive effect on behavioral intention of the respondents to accept digital mortgage service.

Ha3: Social influence has a positive effect on behavioral intention of the respondents to accept digital mortgage service.

Ha4: Facilitating conditions have a positive effect on behavioral intention of the respondents to accept digital mortgage service.

Ha5: Gender, age and technology experience have effects on behavioral intention of the respondents to accept digital mortgage service.

\section{Results and Discussions}

Below are the results of the study:

Hal: Performance expectancy has a positive effect on behavioral intention of the respondents to accept digital mortgage service.

$\mathrm{Ha2}$ : Effort expectancy has a positive effect on behavioral intention of the respondents to accept digital mortgage service.

Ha3: Social influence has a positive effect on behavioral intention of the respondents to accept digital mortgage service.

Ha4: Facilitating conditions have a positive effect on behavioral intention of the respondents to accept digital mortgage service. 
Table 1: Determinants of Behavioral Intention to Accept Digital Mortgage Service

\begin{tabular}{|l|c|c|c|c|}
\hline & $\begin{array}{c}\text { Unstandardized } \\
\text { Coefficients }\end{array}$ & $\begin{array}{c}\text { Standardized } \\
\text { Coefficients }\end{array}$ & $\begin{array}{c}\text { Sig. } \\
(\mathrm{p})\end{array}$ & \\
\hline & $\mathrm{B}$ & Beta & & VIF \\
\hline (Constant) & .011 & & .926 & \\
\hline performance expectancy & .400 & .393 & .001 & 3.061 \\
\hline effort expectancy & .150 & .145 & .010 & 3.089 \\
\hline social influence & .021 & .025 & .575 & 2.030 \\
\hline facilitating conditions & .425 & .400 & .001 & 2.289 \\
Dependent Variable: behavioral intention & & & \\
\hline
\end{tabular}

The results presented in Table 1 revealed that the overall model accounts for $75.2 \%$ of the variance in behavioral intention to accept digital mortgage service. The full model is significant $(\mathrm{F}=186.173, \mathrm{p}=.001)$ and all the variables contribute significantly to the multiple regression (at $\mathrm{p}=0.05$ ) except the variable social influence (SI) which does not relate significantly to the dependent variable $(\mathrm{p}=.575)$ when controlling for the other three predictors.

Table 2: Perceptions of The Respondents on The Four Factors of Behavioral Intention to Accept Digital Mortgage Service

\begin{tabular}{|l|c|c|}
\hline Factor of Behavioral Intention & $\begin{array}{l}\text { Frequency } \\
(\mathrm{n}=250)\end{array}$ & Percent \\
\hline Performance expectancy & 4 & 1.6 \\
\hline strongly disagree & 20 & 8.0 \\
\hline disagree & 125 & 50.0 \\
\hline agree & 101 & 40.4 \\
\hline strongly agree & & .8 \\
\hline Effort expectancy & 2 & 10.0 \\
\hline strongly disagree & 25 & 48.8 \\
\hline disagree & 122 & 40.4 \\
\hline agree & 101 & 5.6 \\
\hline strongly agree & & 12.0 \\
\hline Social influence & 14 & 46.8 \\
\hline strongly disagree & 30 & 35.6 \\
\hline disagree & 117 & .4 \\
\hline agree & 89 & 11.2 \\
\hline strongly agree & & 53.2 \\
\hline Facilitation conditions & 1 & 35.2 \\
\hline strongly disagree & 28 & \\
\hline disagree & 133 & \\
\hline agree & & \\
\hline strongly agree & & \\
\hline & & \\
\hline
\end{tabular}


The respondents' behavioral intention to accept the bank's digital mortgage service is shown in Table 1. Half of the respondents agreed while 38.8 percent agreed on the statements that measured their acceptance to bank's digital mortgage service technology in processing and approval of home loans. Only few of the respondents had an overall response of disagree (9'6\%) and strongly disagree $(1.6 \%)$ on the indicators of behavioral intention to accept the bank's digital mortgage service.

Table 3: Summary of Model and ANOVA

\begin{tabular}{|l|r|r|r|r|r|}
\hline \multicolumn{1}{|c|}{ R } & \multicolumn{1}{|c|}{ R Square } & \multicolumn{1}{|c|}{ Adjusted R Square } & & \\
\hline \multicolumn{1}{|c|}{$867^{\mathrm{a}}$} & \multicolumn{1}{|c|}{.752 } & .748 & & & \\
\hline & Sum of Squares & df & Mean Square & F & Sig. \\
\hline Regression & 90.369 & 4 & 22.592 & 186.173 & .001 \\
\hline Residual & 29.731 & 245 & .121 & & \\
\hline Total & 120.100 & 249 & & & \\
\hline
\end{tabular}

The results led to the acceptance of the following hypotheses: 1) PE positively affects behavioral intention of the respondents to accept digital mortgage service; EE positively affects behavioral intention of the respondents to accept digital mortgage service; and FC positively affects behavioral intention of the respondents to accept digital mortgage service. Meanwhile, the hypothesis that SI positively affects behavioral intention of the respondents to accept digital mortgage service was rejected.

The results concur with the study of Alshehri (2012) who examined the factors affecting acceptance and use of E-government services in the Kingdom of Saudi Arabia by adopting the UTAUT model revealed that trust (TR), effort expectancy (EE), performance expectancy (PE), and website quality (WQ) contribute significantly to citizens' adoption of e-government services and directly affect the behavioral intention to use e-government services in the KSA. The relationship of social influence (SI) on behavioral intention (BI) to use e-government services was insignificant for citizens.

Additionally, Tarhini et al. (2016) who conducted a study that understands the customers' acceptance and use of internet banking in Lebanon revealed that performance expectancy to be a significant predictor in influencing customers' behavioural intention (BI) to use internet banking. However, the same study found that contrary to the UTAUT, the effect of effort expectancy on BI was insignificant.

Moreover, Alalwan, Dwivedib, \& Ranab (2017) in a study on factors influencing adoption of mobile banking by Jordanian bank customers: Extending UTAUT2 with trust mainly showed that behavioural intention is significantly and positively influenced by performance expectancy, effort expectancy, hedonic motivation, price value and trust. On the other hand, the same study revealed that social influence on behavioural intention to adopt mobile banking.

On the other hand, according to the study conducted by Boonsiritomachai, W. \& Pitchayadejanant, K. (2017) with regard to determinants affecting mobile banking adoption by generation $\mathrm{Y}$, it was found that facilitating conditions and self-efficacy in mobile banking application do not exhibit a direct effect on behavioral intention. 
Ha5: Gender, age and technology experience have effects on behavioral intention of the respondents to accept digital mortgage service

Table 4: The Impact of Age, Gender and Technology Experience to Performance Expectancy

\begin{tabular}{|c|c|c|c|}
\hline & $\begin{array}{c}\text { Unstandardized } \\
\text { Coefficients }\end{array}$ & $\begin{array}{l}\text { Standardized } \\
\text { Coefficients }\end{array}$ & Sig. \\
\hline & $\mathrm{B}$ & Beta & \\
\hline (Constant) & 2.421 & & .001 \\
\hline internet knowledge & .164 & .200 & .002 \\
\hline purchase product via mobile device & .285 & .182 & .005 \\
\hline $1=41-50$ yrs old, $0=51 \&$ older & .228 & .158 & .006 \\
\hline $1=$ diploma, $0=$ HS \& below & -.457 & -.249 & .001 \\
\hline
\end{tabular}

a. Dependent Variable: performance expectancy

The significance of the predictors was proven by the rejection of the null (Ho) hypothesis that "There is no significant influence of the predictors (age, gender, education and technology experience) to performance expectancy" at 5\% level of significance. That means, four (4) predictors of performance expectancy as represented by the b-coefficients were found to be significant at 5\% level $(\rho<0.05)$. The stepwise regression corrected the incidence of multicollinearity or redundancy of the predictors in the multiple regression.

Table 5: The Impact of Age, Gender and Technology Experience to Effort Expectancy

\begin{tabular}{lrrr}
\hline & $\begin{array}{c}\text { Unstandardized } \\
\text { Coefficients } \\
\text { B }\end{array}$ & $\begin{array}{c}\text { Standardized } \\
\text { Coefficients } \\
\text { Beta }\end{array}$ & Sig. \\
\hline (Constant) & 3.030 & & .001 \\
purchase product via mobile device & .394 & .254 & .001 \\
internet knowledge & .206 & .254 & .001 \\
$1=41-50$ yrs old, $0=51$ \& older & .220 & .154 & .006 \\
internet time & -.226 & -.178 & .005 \\
$1=$ diploma, $0=$ HS \& below & -.413 & -.227 & .001 \\
\hline
\end{tabular}

Dependent Variable: effort expectancy

The significance of the predictors was proven by the rejection of the null (Ho) hypothesis that "There is no significant influence of the predictors (age, gender, education and technology experience) to effort expectancy" at 5\% level of significance. That means, four (4) predictors of effort expectancy as represented by the b-coefficients were found to be significant at $5 \%$ level $(\rho<0.05)$. The stepwise regression corrected the incidence of multicollinearity or redundancy of the predictors in the multiple regression. 
Table 6: The Impact of Age, Gender and Technology Experience to Social Influence

\begin{tabular}{|l|r|r|r|}
\hline & $\begin{array}{l}\text { Unstandardized } \\
\text { Coefficients }\end{array}$ & $\begin{array}{l}\text { Standardized } \\
\text { Coefficients }\end{array}$ & Sig. \\
\hline & B & Beta & \\
\hline (Constant) & 3.697 & .276 & .001 \\
\hline internet knowledge & .275 & .210 & .001 \\
\hline purchase product via mobile device & .400 & -.140 & .007 \\
\hline $1=31-40$ yrs old, 0 = 51 \& older & -.307 & -.202 & .001 \\
\hline $1=21-30 y r s$ old, 0 = 51 \& older & -.482 & -.289 & .001 \\
\hline internet time & -.451 & -.333 & .001 \\
\hline $1=$ diploma, 0 = HS \& below & -.744 & & \\
\hline
\end{tabular}

Dependent Variable: social influence

The significance of the predictors was proven by the rejection of the null (Ho) hypothesis that "There is no significant influence of the predictors (age, gender, education and technology experience) to social influence" at 5\% level of significance. That means, six (6) predictors of social influence as represented by the b-coefficients were found to be significant at $5 \%$ level $(\rho<0.05)$. The stepwise regression corrected the incidence of multicollinearity or redundancy of the predictors in the multiple regression.

The results of this study partially confirmed the findings of Wang, Wu, \& Wang (2008) which found that found that age differences moderate the effects of effort expectancy and social influence on m-learning use intention, and that gender differences moderate the effects of social influence and self-management of learning on m-learning use intention.

\section{Conclusion}

The research has found that the determinants of behavioral intention to accept digital mortgage device among mortgage clients were facilitating conditions, performance expectancy and effort expectancy. It was also revealed that based on the standardized beta coefficients, facilitating conditions (0.405), performance expectancy (0.383) and effort expectancy (0.134) had significant influence on bank mortgage clients' behavioral intentions to accept digital mortgage service. Additionally, it was also proven that the age, education, computer knowledge and internet knowledge of the mortgage clients moderate the impact of the three determinants: performance expectancy, effort expectancy and social influence on clients' digital mortgage service acceptance. Lastly, it can be concluded that performance expectancy is directly related with internet time, frequency of product purchase using mobile device and use of mobile banking.

\section{Direction for Future Research}

This research has already provided the foundations for using the UTAUT model in relations to bank digitization for bank mortgage services. The future research can initiate including other bank products such as deposits and other investment products.

\section{References}

Alalwana, A., Dwivedib Y., \& Ranab, N. (2017). Factors influencing adoption of mobile banking by Jordanian bank customers: Extending UTAUT2 with trust. International Journal of Information Management. 37 (3), 99-110. 
Amofa, K. K. (2014). Management consultants' acceptance of internet technology: An empirical study of the determinants of web analytics technology acceptance (Order No. 3610402). Available from ABI/INFORM Global. (1499823237). Retrieved from https://search.proquest.com/docview/1499823237?accountid=38643

Boonsiritomachai, W. \& Pitchayadejanant, K. (2017). Determinants affecting mobile banking adoption by generation $\mathrm{Y}$ based on the Unified Theory of Acceptance and Use of Technology Model modified by the Technology Acceptance Model concept. Kasetsart Journal of Social Sciences, 1-10.

Buriak, A. (2014). Performance in banking: theory and practice Pecularities. Munich Personal RePEc Archive.

BusinessWorld. (2018 June 26). The Philippines growth dialogues: unlocking digital banking opportunities. Retrieved from BusinessWorld online: https://www.bworldonline.com/the-philippines-growth-dialogues-unlocking-digitalbanking-opportunities/

Chen, J., Durairaj, S., Vinayak, H. V., \& Lam, K. (2014). Digital banking in Asia: Are you ready for your next generation of customers? Retrieved from https://www.mckinsey.com/ /media/mckinsey/business\%20functions/mckinsey\%20di gital/pdf/2014\%20digital\%20banking\%20in\%20asia\%20-

\%20winning\%20approaches\%20in\%20a\%20new\%20generation\%20of\%20financial\% 20services.ashx

Chiou, J.-S., \& Sen, C.-C. (2012). The antecedents of online financial service adoptation: the impact of physical banking services on internet banking acceptance. Behaviour and information technology, 859-871.

Dragolea, L.-L., Achim, M. I., \& Fleser, M. (2011). Implementing of quality management in banking sector from Romania. Annals of DAAAM \& Proceedings, 685-686.

Holmes, J., Isham, J., Petersen, R., \& Sommers, P. M. (2007). Does Relationship Lending Still Matter in the Consumer Banking Sector? Evidence from the Automobile Loan Market. Social Science Quarterly (Wiley-Blackwell), 585-597.

Malm, E. (2005). Using Transaction-Specific Incentives. Journal of Website Promotion, 93103.

Múčková, V., \& Hrnčiarová, L. (2010). Mortgage in Banking Development in the Slovak Republic. Housing Finance International, 20-31.

Ray, R. (2006). Prediction markets and financial wisdom of crowds. The Journal of Behavioral Finance, 1-4.

Samonte, J. (2013 Feb. 23). Housing loans in the Philippines - approval and processing time comparison guide. Retrieved from Hoppler.com.ph: https://www.hoppler.com.ph/blog/real-estate-tips/housing-loans-in-the-philippinesapproval-and-processing-time-comparison-guide

Scanlon, K., Lunde, J., \& Whitehead, C. (2011). Responding to the housing and financial crises. International Journal of Housing Policy, 23-49.

Tarhini, A., El-Masri, M., Ali, M., \& Serrano, A. (2016). Extending the UTAUT model tounderstand the customers' acceptance and use of internet banking in Lebanon: A structural equation modeling approach. Information Technology \& People,29 (4), pp. 830-849.

Venkatesh, V., Morris, M., Davis, G., \& Davis, F. (2003). User acceptance of information technology: Toward a unified view. MIS Quarterly, 27(3), 425-478.

Wang, Y., Wu, M., \& Wang, H. (2008). Investigating the determinants and age and gender differences in the acceptance of mobile learning. British Journal of Educational Technology, 40 (1), 92-118. 